
Cassandra A. Medvedeff ${ }^{1}$, Scott D. Bridgham ${ }^{2}$, Laurel Pfeifer-Meister ${ }^{2}$, Jason K. Keller ${ }^{1}$ \section{Can Sphagnum Leachate Chemistry Explain Differences in Anaerobic Decomposition in} Peatlands?

$8{ }^{1}$ Chapman University, Department of Earth and Environmental Sciences, 1 University Drive, Orange, CA, 92866,

9 USA. Phone: (714) 289-2038, Fax: (714) 532-6048

$10{ }^{2}$ University of Oregon, Institute of Ecology and Evolution and Environmental Science Institute, Eugene, Oregon 1197403, USA.

12

13

14

15 Corresponding author: C.A. Medvedeff, camedvedeff@gmail.com, medvedef@chapman.edu

16

17

18 Key Words: Methane; carbon cycling; acetoclastic methanogenesis; $\delta^{13} \mathrm{C}_{-} \mathrm{CH}_{4}$, hydrogenotrophic methanogenesis;

19 phenolics

20 
Peatlands are important ecosystems in the global carbon cycle, serving as both the largest

23 terrestrial soil carbon pool and a significant source of the greenhouse gas methane $\left(\mathrm{CH}_{4}\right)$. In

24 Sphagnum moss-dominated wetlands, anaerobic decomposition, and in particular the production

25 of $\mathrm{CH}_{4}$, is highly variable and controlling factors are poorly understood. The main objective of

26 this study was to determine if leachates of Sphagnum can explain differences in anaerobic

27 decomposition and $\mathrm{CH}_{4}$ production from three Sphagnum-dominated peatlands.

28 Soils from each peatland were incubated anaerobically for 40 days with Sphagnum-derived

29 organic matter (S-DOM) extracted using distilled water at 25 or $60^{\circ} \mathrm{C}$ in a fully-crossed

30 experimental design. S-DOM extracted at $25^{\circ} \mathrm{C}$ had a minimal effect on decomposition, but S-

31 DOM extracted at $60{ }^{\circ} \mathrm{C}$ increased $\mathrm{CO}_{2}$ production in all soils. The magnitude of the increased

$32 \mathrm{CO}_{2}$ production in response to $\mathrm{S}-\mathrm{DOM}$ depended on the source site of the S-DOM. The response

33 of $\mathrm{CH}_{4}$ production to additions of $\mathrm{S}-\mathrm{DOM}$ extracted at $60{ }^{\circ} \mathrm{C}$ was more complex. Soils from one

34 peatland produced no $\mathrm{CH}_{4}$ during the incubation, regardless of S-DOM source. The same S-

35 DOM additions led to an increase in $\mathrm{CH}_{4}$ production in a second soil, but a decrease in $\mathrm{CH}_{4}$

36 production in the third soil. Stable isotopic evidence suggests that these patterns were driven by

37 the selective inhibition or stimulation of acetoclastic methanogenesis. Taken together, these data

38 suggest S-DOM alone does not explain differences in anaerobic decomposition in peatlands, but

39 may play a role in regulating $\mathrm{CO}_{2}$ and $\mathrm{CH}_{4}$ production. 


\section{Introduction}

Peatland soils store an estimated $462 \mathrm{Pg}$ of carbon (C), serving as the largest terrestrial

42 soil C pool (Bridgham et al., 2006 and references therein). The vast majority of this soil carbon

43 occurs below the water table, and the fate of this $\mathrm{C}$ is determined, in large part, by anaerobic

44 microbial decomposition which mineralizes stored $\mathrm{C}$ to carbon dioxide $\left(\mathrm{CO}_{2}\right)$ and methane

$45\left(\mathrm{CH}_{4}\right)$. Wetlands are the largest natural source of $\mathrm{CH}_{4}$ to the atmosphere (Bridgham et al., 2013;

46 Kirschke et al., 2013), with peatlands contributing a significant, but poorly constrained fraction

47 of this $\mathrm{CH}_{4}$ flux. Given the effectiveness of $\mathrm{CH}_{4}$ as a greenhouse gas, understanding the controls

48 of peatland decomposition and $\mathrm{CH}_{4}$ dynamics is crucial for understanding feedbacks between

49 these ecosystems and ongoing global change (Bridgham et al., 2013).

50 Many studies have investigated controls of anaerobic decomposition, including $\mathrm{pH}$

51 (Wang et al., 1993; Kotsyurbenko et al., 2007; Ye et al., 2012), temperature (Conrad, 2002;

52 Glissman et al., 2004; Inglett et al., 2012), and nutrient limitation (Keller et al., 2006; Medvedeff

53 et al., 2014) in wetland soils. Despite this work, there is still a great deal of variability in

54 anaerobic decomposition in peatland soils, especially in Sphagnum-dominated ombrotrophic

55 peatland soils, that cannot be fully explained by these controls. For example, Ye et al. (2012)

56 demonstrated that ombrotrophic (bog) peat soils produced less $\mathrm{CH}_{4}$ than minerotrophic (fen) peat

57 soils, even after correcting for soil $\mathrm{pH}$. This suggests that additional controls on anaerobic

58 decomposition have yet to be elucidated.

It is likely that organic matter can play an important role in anaerobic decomposition

60 through multiple mechanisms. While the role of organic matter as a carbon and nutrient source

61 for microbes is well established (Reddy and DeLaune, 2008), recent evidence also suggests that

62 organic matter (i.e., humic substances) can influence anaerobic decomposition and inhibit $\mathrm{CH}_{4}$ 
63 production in ombrotrophic bogs through both antimicrobial properties and by serving as an

64 organic terminal electron acceptor for microbial respiration (Blodau and Deppe, 2012; Keller and

65 Takagi, 2013; Ye et al., unpublished data). Further, the accumulation of phenolic compounds as

66 a result of low phenol oxidase activity under anaerobic conditions in peatlands can inhibit

67 hydrolase enzymes reducing rates of microbial decomposition (Freeman et al., 2001).

One of the main sources of organic matter in peatlands is Sphagnum moss. Sphagnum

69 tissue chemistry is highly variable across species (Rasmussen et al., 1995; Turetsky et al., 2008),

70 which may affect $\mathrm{C}$ mineralization both through its often dominant contribution to the solid peat

71 matrix and through its soluble components. Recent evidence demonstrates that surface DOM

72 permeates throughout the peat profile and often accounts for a substantial fraction of $\mathrm{C}$

73 mineralization even at depth (Chanton et al., 2008; Tfaily et al., 2014). It is well established that

74 the litter of different Sphagnum species decay at very different rates (e.g., Johnson and Damman,

75 1991; Turetsky et al., 2008) and that Sphagnum-derived photosynthate is a known constituent of

76 the soil DOC pool (Fenner et al., 2004). While dissolved organic carbon originating from

77 Sphagnum is highly bioavailable relative to other vegetation such as black spruce (Wickland et

78 al., 2007), this Sphagnum-derived dissolved organic matter (S-DOM) may have complicated

79 effects on anaerobic C cycling beyond its role as a source of labile C. Sphagnum mosses can

80 inhibit the growth of certain microbial species and reduce decomposition rates by acidifying the

81 environment (Stalheim et al., 2009) and releasing polyphenolic compounds, particularly

82 sphagnum acid ( $p$-hydroxy- $\beta$ [carboxymethyl]-cinnamic acid) (Verhoeven and Toth, 1995).

83 Sphagnum acid persists under anaerobic conditions (Swain and Abbott, 2013), suggesting

84 methanogens may be in direct contact with inhibitory Sphagnum-derived phenolic compounds. 
We tested the hypothesis that differences in rates of anaerobic decomposition and $\mathrm{CH}_{4}$

production in Sphagnum-dominated peatlands are influenced by the differences in the S-DOM of the resident Sphagnum species. We hypothesized that (i) S-DOM from peatlands with slow rates of decomposition would inhibit anaerobic decomposition in peatland soils with naturally faster rates of decomposition, and that $\mathrm{CH}_{4}$ production would be particularly sensitive to the S-DOM source, and (ii) the reverse would also be true in that S-DOM from peatlands with fast decomposition would stimulate anaerobic decomposition in soils with slower rates of decomposition.

\section{Materials and Methods}

\subsection{Study Sites and Sample Collection}

The three peatlands for this study are located in northern Minnesota, U.S.A. The poor fen (Bog Lake Fen, N 47³0.304'; W 93 ${ }^{\circ} 29.339^{\prime}$ ) and the weakly ombrotrophic bog (S1 Bog, N 47 $30.388^{\prime}$; W $93^{\circ} 27.256^{\prime}$ ) are in Marcell Experimental Forest of the U.S. Forest Service, approximately $40 \mathrm{~km}$ north of Grand Rapids. The strongly ombrotrophic bog (Zim Bog, N $47^{\circ} 10.745^{\prime}$; W $\left.92^{\circ} 42.877^{\prime}\right)$ is located approximately $40 \mathrm{~km}$ south of the town of Virginia. All three wetlands are dominated by a near complete ground cover of Sphagnum moss. Bog Lake Fen is dominated by a $S$. papillosum Lindb. lawn (Olson et al., 2013), with lesser cover of $S$. capillifolium (Ehrh.) Hedw. and S. magellanicum Brid.. Bog Lake Fen also has extensive cover of sedges (Carex spp., Eriophorum chamissonis C.A. Mey) and occasional northern pitcher plants (Sarracenia purpurea L.) and ericaceous shrubs such as leather leaf (Chamaedaphne calyculata (L.) Moench) and bog cranberry (Vaccinium macrocarpun Aiton) (Kolka et al., 2011; Olson et al., 2013). The water-table depth at Bog Lake Fen averaged $-7.0 \mathrm{~cm}$ during sampling 

123 1998).

on July 18-20, 2013. S1 Bog contains pronounced hummock-hollow topography with hummocks dominated by S. magellanicum Brid. and hollows dominated by S. angustifolium (C.E.O. Jensen ex Russow) C.E.O. Jensen and S. fallax (Klinggr.) Klinggr. (D. Weston, personal communication). The S1 Bog overstory is comprised of black spruce (Picea mariana (Mill.) Britton, Sterns \& Poggenb.) and tamarack (Larix laricina (Du Roi) K. Koch) with the understory containing ericaceous shrubs including leather leaf, Labrador tea (Rhododendron groenlandicum Oeder), and bog rosemary (Andromeda polifolia L.), forbs such as three-leaved false Solomon's seal (Smilacina trifolia (L.) Sloboda) and northern pitcher plant, and sedges such as three-seeded sedge (Carex trisperma Dewey) and cotton grass (Eriophorum spissum Fernald)

(http://mnspruce.ornl.gov/content/detailed-site-description). Water-table levels at S1 Bog in July 2013 averaged $-6.6 \mathrm{~cm}$ and $-15.2 \mathrm{~cm}$ in hollows and hummocks, respectively. Zim Bog is dominated by a large, expansive hummock with a few sparse, but deep, hollows and was the driest of the sites with an average water-table depth of -18.8 and $-33.2 \mathrm{~cm}$ in hollows and hummocks, respectively, in July 2013. Zim Bog has a moss layer dominated by S. fuscum and an overstory consisting of black spruce and similar ericaceous shrubs to S1 Bog (Bridgham et al.,

Peat cores $(\sim 25 \mathrm{~cm}$ depth) were collected from immediately below the water table in the hollows of each site using a serrated knife ( $\mathrm{n}=3$ cores per site) at Bog Lake and S1 Bog and a Russian Corer at Zim Bog because of its low water table. Soil pH averaged 4.2, 4.0, and 3.8 for Bog Lake Fen, S1 Bog, and Zim Bog, respectively (Table 1). In addition to soil collection, live Sphagnum composite (top 0-5 cm) grab samples were collected from S1 Bog hollows in July 2013. Additional Sphagnum composite (top 0-5 cm) grab samples were collected from the lawn of Bog Lake Fen, Zim Bog hummocks, and S1 Bog hummocks on September $15^{\text {th }}-17^{\text {th }}, 2013$. 
131 We chose to use composite Sphagnum samples instead of sorting them by species because we

132 had previously identified that soils from these 3 sites have very different rates of anaerobic C

133 mineralization (unpublished data, also Table 1) and wanted to accurately represent the Sphagnum

134 community at each site to determine if this could potentially explain these differences. Because

135 of the constant depth increment used and variable growth among species, Sphagnum age likely

136 varied among species across sites which could affect nutrient quantity and quality in subsequent

137 extracts. Following collection, soil and Sphagnum samples were placed on ice, shipped to

138 Chapman University, and frozen until further analysis.

139

140

141

142

143

144

145

146

147

148

149

150

151

152

153

\subsection{Anaerobic Laboratory Incubations}

To explore the effects of Sphagnum leachate on anaerobic decomposition, we added Sphagnum-derived dissolved organic matter (S-DOM) extracted from each site to the soil from each site in a fully crossed experimental design. S-DOM was prepared by extracting $10 \mathrm{~g}$ dry weight equivalent of Sphagnum from each site (Bog Lake Fen, S1 Bog hummock, S1 Bog hollow and Zim Bog hummock) with $200 \mathrm{~mL}$ of deionized water at either $25^{\circ} \mathrm{C}$ or $60{ }^{\circ} \mathrm{C}$ for 48 hours $\left(\mathrm{S}-\mathrm{DOM}_{25}\right.$ and $\mathrm{S}-\mathrm{DOM}_{60}$, respectively). To ensure that all soils received identical S-DOM additions in subsequent incubations, there was a single extraction for each Sphagnum community. Following extraction, samples were filter-sterilized with a $0.2 \mu \mathrm{m}$ filtration system (Millipore, stericup), and the $\mathrm{pH}$ of each extract was adjusted to match the $\mathrm{pH}$ measured at each site following pre-incubation. Our intent was not to represent in situ conditions with these extraction temperatures; rather, they were utilized to extract DOM of different complexity from Sphagnum and explore the effect of these extracts on anaerobic decomposition in three different peat soils. We anticipated that higher extraction temperatures would yield S-DOM with higher concentrations of phenolics and proteins (Herranz et al., 2006) and elevated dissolved organic 
154 carbon concentrations resulting from cell lyses and increased degradation of molecules of greater 155 complexity (Gregorich et al., 2003, and references therein). It is likely that over prolonged 156 periods of decomposition (as opposed to the 48 hour leaching period) that the compounds 157 leached at $60{ }^{\circ} \mathrm{C}$ would become increasing available at in situ temperatures.

Phenolics, dissolved organic C (DOC), protein absorbance, and specific ultra-violet absorbance (SUVA) were measured on all S-DOM extracts. Total soluble phenolics were 160 quantified using a Folin-Ciocalteu assay (AOAC, 1950) with standard curves based on gallic 161 acid (GA) equivalents at $760 \mathrm{~nm}$ wavelength on a Shimadzu UV-1700 spectrophotometer

162 (Tokyo, Japan). DOC concentrations were analyzed following the persulfate digestion method 163 (modified from Horwath and Paul, 1994), and $\mathrm{CO}_{2}$ was measured on a gas chromatograph using 164 a flame ionization detector equipped with a methanizer (SRI Instruments, Torrance, CA, USA). 165 166 $254 \mathrm{~nm}$ for SUVA determinations and $278 \mathrm{~nm}$ for protein absorbance determinations (Stevens,

167 1992); nanopure water was used as the blank for both analyses. Samples were warmed to room 168 temperature prior to analysis in a quartz cell cuvette with a $1.0 \mathrm{~cm}$ path. Specific ultraviolet 169 absorbance $\left(\mathrm{SUVA}_{254}\right)$ was quantified as a proxy for dissolved $\mathrm{C}$ quality by dividing the UV 170 absorbance $254 \mathrm{~nm}$ by the DOC concentration. Values were reported as $\mathrm{L} \mathrm{mg}^{-1} \mathrm{C} \mathrm{m}^{-1}$ (Weishaar et 171 al., 2003).

172 Large roots and woody debris were removed from the soils, and the 3 cores from each 173 site were homogenized. Ten grams of wet weight soil were added to $160-\mathrm{mL}$ serum bottles 174 ( $\mathrm{n}=27$ for each site) and pre-incubated for 22 days at $18{ }^{\circ} \mathrm{C}$ (the approximate in situ soil 175 temperature in July 2013) prior to addition of S-DOM extracts to facilitate consumption of 176 terminal electron acceptors. Additional aliquots of field-moist soil from each homogenized 
177 sample ( $\mathrm{n}=3$ per site) were dried at $60{ }^{\circ} \mathrm{C}$ to a constant mass for moisture content determination.

178 Following drying, samples were ground through a Wiley Mill fitted with a 40-mesh screen

179 (Thomas Scientific, Swedesboro, NJ, USA) and analyzed for total C (TC) and total nitrogen

180 (TN) with a Costech 4010 elemental analyzer (Valencia, CA). At the end of the 22 day pre-

181 incubation, sacrificial samples ( $\mathrm{n}=3$ per site) were filtered through a $0.45 \mu \mathrm{m}$ filter and analyzed

182 for $\mathrm{pH}$, phenolic concentrations, DOC, protein absorbance, and SUVA to determine initial

183 dissolved organic matter chemistry (Table 1, 2).

In an anaerobic chamber (Coy Laboratory Products Inc., Grass Lake, MI, USA), 10 mL

185 S-DOM extracts and $10 \mathrm{~mL}$ of nanopure water were added to pre-incubated soil slurries in a

186 fully-crossed experimental design (3 soils, 4 S-DOM extracts, 2 extraction temperatures, $\mathrm{n}=3$ ).

187 After the addition of S-DOM, $\mathrm{pH}$ was measured on all samples following a 30 minute

188 equilibration period to verify that the S-DOM did not change acidity. Serum bottles were sealed

189 and flushed with $\mathrm{N}_{2}$ for 15 minutes to ensure anaerobic conditions.

190

In addition to the S-DOM treatments, soil-only controls (10 g soil : $20 \mathrm{~mL}$ nanopure

water) and S-DOM extract controls were analyzed concurrently ( $\mathrm{n}=3$ per treatment). Headspace

192 gas was analyzed for $\mathrm{CO}_{2}$ and $\mathrm{CH}_{4}$ on days $1,3,5,9,12,17,19,26,33$, and 40. Slurries were

193 opened in the anaerobic chamber, soil $\mathrm{pH}$ was measured, and bottles were re-capped and flushed

194 with $\mathrm{N}_{2}$ weekly. Total $\mathrm{CO}_{2}$ and $\mathrm{CH}_{4}$ production were calculated after correcting for pressure,

195 solubility and pH (Drever, 1997; Bridgham and Ye, 2013). Cumulative $\mathrm{CO}_{2}$ and $\mathrm{CH}_{4}$ production

196 were calculated by summing production on each sampling date, and the total production was

197 expressed as $\mu$ moles of gas per $\mathrm{g}$ dry weight soil after the 40 day incubation. After 40 days,

198 headspace gas samples were injected into 12-mL Exetainers (LABCO Ltd.; www.labco.uk.com)

199 and shipped to the University of California, Davis Stable Isotope Facility for $\delta^{13} \mathrm{C}-\mathrm{CH}_{4}$ analysis. 
200 In addition, soil samples were extracted (as described previously) and analyzed for soluble

201 phenolics, DOC, protein absorbance, and SUVA on day 40.

202

203

\subsection{Statistical Analyses}

204

To determine initial and final site differences in soil and S-DOM properties as well as

$205 \mathrm{CO}_{2}$ and $\mathrm{CH}_{4}$ production, values were compared via one-way Analysis of Variance (ANOVA).

206 Following significant $(\alpha<0.05)$ ANOVAs, post-hoc Tukey's HSD was used to test for treatment

207 differences. Normality was determined via the Shapiro Wilk goodness-of-fit test. To achieve

208 normality, data for phenolic concentrations, SUVA, protein absorbance, and total $\mathrm{CO}_{2}$

209 production were log transformed prior to analysis. Regressions were run on S-DOM-derived gas

210 production $\left(\mathrm{CO}_{2}\right.$ and $\left.\mathrm{CH}_{4}\right)$ versus $\mathrm{S}$-DOM-derived DOC and protein absorbance. S-DOM-

211 derived effects were calculated as follows: $\left(\mathrm{X}_{1}-\mathrm{X}_{2}\right)$, where $\mathrm{X}_{1}=$ value following incubation with

$212 \mathrm{~S}-\mathrm{DOM}$ and $\mathrm{X}_{2}=$ value following incubation with no S-DOM. All statistical analyses were run in

213 JMP v. 8.0 (SAS institute, Cary NC).

214

215 3. Results

216 3.1. S-DOM and Initial Soil Properties

217 3.1.2. Prior to incubation

218 To ensure uniformity of S-DOM additions, a single extraction was completed for each

219 Sphagnum type at each temperature. All S-DOM additions were sources of phenolics, DOC, and

220 protein with higher concentrations coinciding with higher extraction temperatures (Table 2).

221 Following the 22 day pre-incubation, soil properties were compared among Bog Lake

222 Fen, S1 Bog, and Zim Bog (Table 1). pH was highest in Bog Lake Fen soil, followed by S1 
223 Bog, and Zim Bog $(P<0.0001)$. Soil TC was greatest in $\mathrm{S} 1 \mathrm{Bog}(P<0.05)$. TN concentrations in

224 S1 Bog were double that of Zim Bog, with intermediate concentrations in Bog Lake Fen

$225(P<0.05)$. Differences in TC:TN were primarily driven by differences in TN, with the highest

226 ratio found in Zim Bog, followed by Bog Lake Fen, and the lowest ratio (approximately half that

227 of Zim Bog) in S1 Bog soils $(P<0.05)$.

$228 \mathrm{CO}_{2}$ production during the pre-incubation period was greatest in Bog Lake Fen soil,

229 followed by S1 Bog and then Zim Bog soils $\left(P<0.0001\right.$, Table 1). $\mathrm{CH}_{4}$ production from Zim

230 Bog soil was below detection (reflecting a maximum rate of $0.0007 \mu \mathrm{mol} \mathrm{g}^{-1} \mathrm{dw}_{\text {soil d }}{ }^{-1}$ ) during

231 both the pre-incubation and incubation. $\mathrm{CH}_{4}$ production was approximately 4 -fold greater in $\mathrm{S} 1$

232 Bog relative to Bog Lake Fen during the pre-incubation period $(P<0.05$, Table 1$)$. No significant

233 differences in initial dissolved phenolics, DOC, SUVA, or protein absorbance were observed

234 between sites after the pre-incubation period and prior to the addition of S-DOM (Supplemental

$2351)$.

236

\subsection{Response to S-DOM Amendments}

238

Although trends between extraction temperatures were similar, the magnitude of the

239 response of $\mathrm{CO}_{2}$ and $\mathrm{CH}_{4}$ production to the $\mathrm{S}-\mathrm{DOM}_{25}$ addition in each soil (Supplemental 2 and

240 3) was much smaller than that observed following S-DOM 60 addition. The addition of S-DOM 25

241 from all sources stimulated $\mathrm{CO}_{2}$ production in Bog Lake Fen and S1 Bog soils, but only S1 Bog

242 hollow $\mathrm{S}-\mathrm{DOM}_{25}$ stimulated $\mathrm{CO}_{2}$ production in Zim Bog soils (Supplemental 2). Furthermore,

$243 \mathrm{~S}_{-} \mathrm{DOM}_{25}$ from $\mathrm{S} 1$ Bog hummocks suppressed $\mathrm{CH}_{4}$ production while $\mathrm{S} 1$ Bog hollow S-DOM 25

244 stimulated $\mathrm{CH}_{4}$ production in Bog Lake Fen soil (Supplemental 3). Addition of Bog Lake Fen

245 and $\mathrm{S} 1$ Bog hollow S-DOM 25 to $\mathrm{S} 1 \mathrm{Bog}$ soil stimulated $\mathrm{CH}_{4}$ production. S-DOM 25 from Zim 
246 Bog did not affect $\mathrm{CH}_{4}$ production in either $\mathrm{S} 1$ Bog or Bog Lake Fen soil. There was no effect 247 of $\mathrm{S}-\mathrm{DOM}_{25}$ on $\delta^{13} \mathrm{C}-\mathrm{CH}_{4}$ in Bog Lake Fen soil; in contrast, addition of S1 Bog hollow S-DOM 25 248 enriched values when added to S1 Bog soil (Supplemental 3). Overall, we saw the largest effect 249 of $\mathrm{S} 1$ Bog hollow S-DOM 25 on $\mathrm{CO}_{2}$ and $\mathrm{CH}_{4}$ production relative to all other S-DOM additions.

250 This large response, regardless of site, was likely driven by the high DOC and protein

251 concentrations coupled with a low SUVA value and low phenolic content in the extract (Table 252 2).

The addition of $\mathrm{S}-\mathrm{DOM}_{60}$ stimulated $\mathrm{CO}_{2}$ production in soils from all sites, but the 254 magnitude of response depended on the source of the S-DOM within soil type (Figure 1). In Bog 255 Lake Fen soil, the greatest stimulation of $\mathrm{CO}_{2}$ was in response to $\mathrm{S}-\mathrm{DOM}_{60}$ from $\mathrm{S} 1 \mathrm{Bog}$ 256 hummocks, followed by S-DOM 60 from Bog Lake Fen and then S-DOM 60 from S1 Bog hollows 257 and Zim Bog $\left(P<0.0001\right.$, Figure 1a). Similarly, $\mathrm{CO}_{2}$ production from $\mathrm{S} 1$ Bog soil was 258 stimulated to the greatest extent by S-DOM 60 from the S1 Bog hummock, followed by Bog Lake 259 Fen S-DOM $_{60}$, S1 Bog hollow S-DOM 60 , and Zim Bog S-DOM $60(P<0.0001$, Figure 1b). In Zim 260 Bog soil, $\mathrm{CO}_{2}$ production was greatest when amended with $\mathrm{S} 1$ Bog hummock S-DOM60, 261 intermediate when amended with S1 Bog hollow and Bog Lake Fen S-DOM 60 , and lowest when 262 amended with Zim Bog S-DOM $60(P<0.0001$, Figure 1c).

S-DOM addition inhibited $\mathrm{CH}_{4}$ production in Bog Lake Fen soil, regardless of S-DOM 264 origin $(P=0.0038$, Figure $2 \mathrm{a})$. In contrast, $\mathrm{S}-\mathrm{DOM}_{60}$ stimulated $\mathrm{CH}_{4}$ production in $\mathrm{S} 1$ Bog soil $265(P<0.0001)$. The greatest stimulation of $\mathrm{CH}_{4}$ production was in response to $\mathrm{S}-\mathrm{DOM} 60$ from $\mathrm{S} 1$ 266 Bog hollow, followed by Bog Lake Fen, and then S1 Bog hummock and Zim Bog $(P<0.0001$, 267 Figure 2b). 
In Bog Lake Fen soil, S-DOM 60 additions yielded depleted $\delta^{13} \mathrm{C}-\mathrm{CH}_{4}$ relative to the unamended control ( $P=0.0005$, Figure $2 \mathrm{a})$, although this depletion was not significant for Zim Bog S-DOM. In contrast, the addition of S-DOM 60 resulted in more enriched $\delta^{13} \mathrm{C}-\mathrm{CH}_{4}$ compared to unamended controls in $\mathrm{S} 1 \mathrm{Bog}$ soil $(P<0.0001$, Figure $2 \mathrm{~b})$.

S-DOM $60^{-}$-derived $\mathrm{CO}_{2}$ was positively correlated to the increase of DOC in response to S$\mathrm{DOM}_{60}$ amendments in Bog Lake Fen soil $\left(\mathrm{R}^{2}=0.54, P=0.0067\right)$ and Zim Bog soil $\left(\mathrm{R}^{2}=0.79\right.$, $P=0.0003$ ) (Figure 3a, c); however, this relationship was not significant in $\mathrm{S} 1$ Bog soil $\left(\mathrm{R}^{2}=0.24\right.$, $P=0.104$ ) (Figure 3b). Similarly, increasing protein absorbance as a result of $\mathrm{S}-\mathrm{DOM}_{60}$ amendment was positively correlated with S-DOM $60^{-}$derived $\mathrm{CO}_{2}$ in $\mathrm{Bog}$ Lake Fen and Zim Bog soils but not in $\mathrm{S} 1$ Bog soil (data not shown). $\mathrm{CH}_{4}$ production was not correlated to S-DOM $60^{-}$ derived DOC or protein in $\mathrm{S} 1 \mathrm{Bog}$, but increasing DOC was correlated with the decreasing $\mathrm{CH}_{4}$ production observed in Bog Lake Fen soil (Figure 3d-e).

When focusing on the S-DOM 60 only controls, Sphagnum origin had no effect on phenolic concentrations or SUVA at the end of the incubation (Supplemental 4). However, DOC and protein concentrations were highest in $\mathrm{S}^{-\mathrm{DOM}_{60}}$ from $\mathrm{S} 1$ Bog hummocks and DOC concentrations were lowest in S-DOM 60 from Zim Bog.

The addition of S-DOM 60 increased soil DOC concentrations in Bog Lake Fen, Zim Bog, and S1 Bog soils, with the exception of the addition of S-DOM 60 from Zim Bog added to S1 Bog soil (Supplemental $5 \mathrm{a}-\mathrm{c}$ ). The $\mathrm{S}-\mathrm{DOM}_{60}$ amendment had no significant effect on phenolic concentrations (Supplemental 5 d-f) or SUVA (Supplemental 6 a-c) in any soil. Protein absorbance in Bog Lake Fen soil increased when amended with S-DOM 60 from S1 Bog or Bog Lake Fen (Supplemental 6 d), but no significant effect was observed in the other two soils (Supplemental 6 e-f). Concentrations of DOC and phenolics were similar pre- and post- 
291 incubation in the unamended control (Supplemental 1). Higher values of SUVA post-incubation

292 compared to pre-incubation suggest that DOM became increasingly recalcitrant over the course

293 of the incubation in unamended soils from S1 Bog $(P=0.0134)$, although this pattern was not

294 observed in Bog Lake Fen or Zim Bog soil (Supplemental 1). Similarly, protein absorbance

295 increased over the incubation in S1 Bog soils without amendment $(P=0.0415$, Supplemental 1).

296 4. Discussion

297

Sphagnum is the dominant source of carbon in many ombrotrophic peatlands. There is

298 abundant evidence that it affects $\mathrm{C}$ cycling through the quality of the litter and the subsequent

299 peat that it produces in the solid form (Johnson and Damman, 1991; Verhoeven and Toth, 1995).

300 Additionally, photosynthate from Sphagnum is a known constituent of the soil DOC pool

301 (Fenner et al., 2004). This suggests DOM leached from living Sphagnum could stimulate

302 anaerobic decomposition in these ecosystems by the addition of labile C (Tfaily et al., 2014) or

303 inhibit it due high concentrations of inhibitory phenolic compounds (Verhoeven and Toth, 1995;

304 Freeman et al., 2004; Ye et al., unpublished data), which vary widely among Sphagnum species

305 (Turetsky et al., 2008). Moreover, a substantial fraction of anaerobic C mineralization can come

306 from DOM, even at depths of up to $200 \mathrm{~cm}$ below the soil surface (Chanton et al., 2008; Tfaily et

307 al., 2014) suggesting that S-DOM could potentially influence microbial processes through the

308 peat profile.

We utilized two extraction temperatures $\left(25^{\circ} \mathrm{C}\right.$ and $\left.60^{\circ} \mathrm{C}\right)$ to generate S-DOM in our

310 experiment and explored the effects of this S-DOM on anaerobic decomposition in three

311 peatland soils. Similar to past leachate experiments (e.g., Herranz et al., 2006), extraction at 60

$312{ }^{\circ} \mathrm{C}$ generally resulted in higher concentrations of phenolics, DOC and protein than the extraction

313 at $25^{\circ} \mathrm{C}$ (Table 2, Supplemental 3). No short-term extraction at a single temperature will 
314 adequately represent leachates from organic matter in situ, so leachates at the two temperatures

315 more accurately represents the potential spectrum of S-DOM effects on anaerobic mineralization

316 in the long term. While we focus on the effect of the $60{ }^{\circ} \mathrm{C} \mathrm{S}$-DOM extracts on anaerobic

317 decomposition, the effects on $\mathrm{CO}_{2}$ and $\mathrm{CH}_{4}$ production were generally similar for $25{ }^{\circ} \mathrm{C} \mathrm{S}$-DOM

318 extracts, even though the magnitude of the effects were considerably smaller. The smaller

319 responses to $\mathrm{S}-\mathrm{DOM}_{25}$ were likely due to lower concentrations of DOC and protein with the

320 more recalcitrant carbon (based on SUVA values) in the S-DOM 25 compared to the S-DOM 60

321 (with S1 Bog hollow SUVA values as the exception).

We initially hypothesized that the chemistry of S-DOM would exert a major control on

323 anaerobic decomposition such that S-DOM from Sphagnum at sites with slow rates of anaerobic

324 decomposition would inhibit decomposition in soils with faster rates of decomposition, and S-

325 DOM from sites with fast rates of decomposition would stimulate decomposition in soils with

326 slow rates of decomposition. Our results show a major effect of S-DOM 60 on anaerobic C

327 cycling, but in a much more nuanced way than the site-specific responses of $\mathrm{CO}_{2}$ and $\mathrm{CH}_{4}$

328 production that we originally hypothesized. The relationship between the added organic $\mathrm{C}$ and

329 protein contained in S-DOM and the $\mathrm{CO}_{2}$ response in two of the soils (Figure 3 a, c) suggests the

330 availability of labile $\mathrm{C}$ in $\mathrm{S}-\mathrm{DOM}$ was an important factor explaining the relative responses

331 among sources. A great deal of previous work suggests that overall anaerobic decomposition in

332 peatland soils is limited by the availability of labile C (Segers, 1998 and references therein).

333 Given our pre-incubation of 22 days, the majority of terminal electron acceptors (TEAs) in peat

334 matrix were probably reduced before S-DOM addition, and any TEAs in the S-DOM would have

335 been consumed early in the 40-day incubation period (Keller and Takagi, 2013), so the

336 stimulated $\mathrm{CO}_{2}$ production was likely primarily due to fermenters. 
The response of $\mathrm{CH}_{4}$ production to S-DOM amendments was more complex. Soil from

338 Zim Bog produced no $\mathrm{CH}_{4}$ over the course of this experiment, regardless of S-DOM addition.

339 The reasons for this are unclear, but it is worth noting that the lack of $\mathrm{CH}_{4}$ production continued

340 even in the presence of microbially-accessible $\mathrm{S}-\mathrm{DOM}$ which stimulated $\mathrm{CO}_{2}$ production in this

341 soil and was utilized by methanogens in one of the other soils in this experiment (S1 Bog soil).

342 Slow rates of $\mathrm{CH}_{4}$ production in anaerobic laboratory incubations are common in ombrotrophic

343 soils (Bridgham et al., 2013 and references therein) and have been explained by a number of

344 mechanisms. Low $\mathrm{CH}_{4}$ production can be the result of competitive inhibition by microbial

345 reduction of more thermodynamically favorable TEAs (Dettling et al., 2006). It is also possible

346 that the reduction of these TEAs could be used in the process of anaerobic methane oxidation

347 (Gupta et al., 2013). However as stated above, all TEAs were likely reduced during the long

348 incubation (Keller and Takagi, 2013). Another possibility is that compounds in this soil, derived

349 from Sphagnum or other vegetation, selectively inhibited methanogens. For example, phenolic

350 compounds are known to have antimicrobial properties affecting certain microorganisms

351 (Fernández et al., 1996; Mellegård et al., 2009; Stalheim et al., 2009), including some types of

352 methanogens (Puyol et al., 2012). In addition, phenolic compounds can reduce hydrolase

353 enzyme activity substantially (Freeman et al., 2001) ultimately affecting decompositions rates.

354 However, soluble phenolics were not higher in Zim Bog soil compared to other soils

355 (Supplement 1). In addition, S-DOM had no effect on the phenolic:DOC ratio (data not shown)

356 suggesting modification of the inhibitory effect of phenolics was not affected by S-DOM

357 addition (Freeman et al., 1990). The lower soil pH (Table 1) at Zim Bog could have also

358 inhibited methanogens; however, factors in addition to $\mathrm{pH}$ may also be important (Ye et al.,

359 2012). 
S-DOM amendments led to increased $\mathrm{CH}_{4}$ production in $\mathrm{S} 1$ Bog soil, suggesting that

361 labile substrates in S-DOM were made available to methanogens in addition to $\mathrm{CO}_{2}$-producing

362 microbes in this soil. However, the amount of excess $\mathrm{CH}_{4}$ produced in response to S-DOM

363 amendments in $\mathrm{S} 1$ Bog soil was small compared to the amount of excess $\mathrm{CO}_{2}$ produced in the

364 same soil. S-DOM-derived $\mathrm{CO}_{2}: \mathrm{CH}_{4}$ ratios ranged from 12 to 477 across the S-DOM

365 treatments. These ratios are significantly higher than the 1:1 ratio of $\mathrm{CO}_{2}: \mathrm{CH}_{4}$ expected during

366 anaerobic decomposition under conditions where methanogenesis is not inhibited by TEA

367 reduction (Conrad, 1999). Such high ratios are common in soil incubation experiments (Segers,

3681998 and references therein), including incubations with C additions (Dettling et al., 2006), and

369 may reflect $\mathrm{CO}_{2}$ production from fermentation, respiratory reduction, and anaerobic methane

370 oxidation (Bridgham et al., 2013).

371 The $\delta^{13} \mathrm{C}-\mathrm{CH}_{4}$ values provide insights into the mechanism of the $\mathrm{CH}_{4}$ responses.

372 Methane produced through the hydrogenotrophic pathway (the reduction of $\mathrm{CO}_{2}$ coupled to the

373 oxidation of $\mathrm{H}_{2}$ ) has $\delta^{13} \mathrm{C}-\mathrm{CH}_{4}$ values in the range of $-80 \%$ o to $-110 \%$ o. In contrast, $\mathrm{CH}_{4}$ produced

374 from the acetoclastic pathway (the splitting of acetate to $\mathrm{CO}_{2}$ and $\mathrm{CH}_{4}$ ) has more enriched values

375 of $\delta^{13} \mathrm{C}_{-} \mathrm{CH}_{4}$ in the range of $-50 \%$ o to $-60 \%$ (Whiticar, 1999). In the $\mathrm{S} 1 \mathrm{Bog}$ soil, enriched $\delta^{13} \mathrm{C}-$

$376 \mathrm{CH}_{4}$ produced in response to S-DOM amendments suggests a greater contribution of acetoclastic

377 methanogenesis and/or a decrease in $\mathrm{CH}_{4}$ produced by hydrogenotrophic methanogenesis.

378 Methane oxidation also results in enriched $\delta^{13} \mathrm{C}-\mathrm{CH}_{4}$ values (Whiticar, 1999), but it seems

379 unlikely that $\mathrm{CH}_{4}$ oxidation dominated S1 Bog soils amended with S-DOM due to the observed

380 higher net $\mathrm{CH}_{4}$ production (Figure $2 \mathrm{~b}$ ).

In contrast to the response in $\mathrm{S} 1$ Bog soil, $\mathrm{S}-\mathrm{DOM}$ amendments inhibited $\mathrm{CH}_{4}$ production

382 in Bog Lake Fen soil (Figure 2a). Lower net $\mathrm{CH}_{4}$ production could be caused by increased rates 
383 of anaerobic $\mathrm{CH}_{4}$ oxidation, but this seems unlikely given the depleted $\delta^{13} \mathrm{C}-\mathrm{CH}_{4}$ signature

384 observed in response to the S-DOM amendment in Bog Lake Fen soil (Figure 2a). Instead, the

385 lower net $\mathrm{CH}_{4}$ production and depleted $\delta^{13} \mathrm{C}-\mathrm{CH}_{4}$ values suggest that $\mathrm{S}$-DOM amendments

386 selectively inhibited acetoclastic methanogenesis. This conclusion supports a previous study

387 which found more pronounced inhibition of the acetoclastic relative to hydrogenotrophic

388 methanogenesis following exposure to specific chlorophenolic compounds (Puyol et al., 2012).

389 In addition to a direct inhibition of methanogenesis, S-DOM could have resulted in the

390 competitive inhibition of $\mathrm{CH}_{4}$ production if oxidized TEAs were introduced in the S-DOM

391 amendments, although this should have been a transitory effect. Regardless of the specific

392 mechanisms of inhibition, it is curious that identical S-DOM amendments caused diametrically

393 opposite effects on $\mathrm{CH}_{4}$ production in the two soils, apparently mediated through differential

394 responses of the acetoclastic methanogenesis. Future work exploring microbial community

395 shifts could provide insights into these responses.

396

397 5. Conclusions

398 We demonstrate that DOM leached from Sphagnum has large effects on anaerobic C

399 cycling and that the effects of $\mathrm{S}-\mathrm{DOM}$ on $\mathrm{CO}_{2}$ and $\mathrm{CH}_{4}$ are mediated by the source of the

400 Sphagnum and differ between soils. The effects of S-DOM were clearer following addition of S-

401 DOM $_{60}$ which contained higher concentrations of phenolics, DOC, protein, and contained a

402 lower SUVA value relative to $\mathrm{S}-\mathrm{DOM}_{25}$ extracts. It is likely that lower concentrations of these

403 compounds and higher SUVA values in $\mathrm{S}-\mathrm{DOM}_{25}$ extracts limited the responses compared to the

$404 \mathrm{~S}-\mathrm{DOM}_{60}$ amendments. Given new evidence that recent plant-derived DOM diffuses throughout

405 the peat profile, this suggests that changes in Sphagnum communities driven by climate change 
could have large effects on anaerobic $\mathrm{C}$ cycling within the peat profile. $\mathrm{CO}_{2}$ production increased in response to S-DOM amendments in all soil types, suggesting that labile substrates extracted from Sphagnum were utilized by fermenting bacteria. The response of $\mathrm{CH}_{4}$ production was complex, and ranged from increased $\mathrm{CH}_{4}$ production in one soil to inhibition of $\mathrm{CH}_{4}$ production in another soil. This response was apparently largely driven by selective inhibition or stimulation of methanogenic pathways which varied between sites. The mechanistic controls of Sphagnum-derived DOM on anaerobic decomposition need to be further addressed given the dramatic effects observed in this study.

Acknowledgments. This material is based on work supported by the U.S. Department of Energy Office of Science, Office of Biological and Environmental Research under award number DE-SC0008092. We would like to thank P. Hanson, R. Kolka, D. Kyllander, D. Olson, R. Nettles IV, and the rest of the SPRUCE and Marcell Experimental Forest team. In particular, the research teams of J. Chanton (Florida State University) and J. Kostka (Georgia Institute of Technology) provided field assistance and intellectual support. Access to Zim Bog was provided by St. Louis County, MN.

\section{Literature Cited.}

AOAC (1950) Official methods of analysis of the Association of Official Agricultural Chemists $7^{\text {th }}$ edn. Association of Official Agricultural Chemists, Washington DC.

Blodau, C., Deppe, M., 2012. Humic acid addition lowers methane release in peats of the Mer Bleue bog, Canada. Soil Biology and Biochemistry 52, 96-98. 
428 Bridgham, S.D., Cadillo-Quiroz, H., Keller, J.K., Zhuang, Q., 2013. Methane emissions from wetlands: biogeochemical, microbial, and modeling perspectives from local to global scales. Global Change Biology 19, 1325-1346.

431

432

433

434

435

436

437

438

439

440

441

442

443

444

445

446

447

448

449

Bridgham, S.D., Megonigal, J.P., Keller, J.K., Bliss, N.B., Trettin, C., 2006. The carbon balance of North American wetlands. Wetlands 26, 889-916.

Bridgham, S.D., Updegraff, K., Pastor, J., 1998. Carbon, nitrogen, and phosphorus mineralization in northern wetlands. Ecology 79, 1545-1561.

Bridgham, S.D., Ye, R., 2013. Organic Matter Mineralization and Decomposition, In: R.D.

DeLaune, K.R.R., C.J. Richardson, and P. Megonigal (Ed.), Methods in Biogeochemistry of Wetlands, pp. 253-274.

Chanton, J., Glaser, P., Chasar, L., Burdige, D., Hines, M., Siegel, D., Tremblay, L., Cooper, W., 2008. Radiocarbon evidence for the importance of surface vegetation on fermentation and methanogenesis in contrasting types of boreal peatlands. Global Biogeochemical Cycles 22, GB4022.

Conrad, R., 1999. Contribution of hydrogen to methane production and control of hydrogen concentrations in methanogenic soils and sediments. FEMS Microbiology Ecology 28, 193-202.

Conrad, R., 2002. Control of microbial methane production in wetland rice fields. Nutrient Cycling in Agroecosystems 64, 59-69.

Dettling, M.D., Yavitt, J.B., Zinder, S.H., 2006. Control of organic carbon mineralization by alternative electron acceptors in four peatlands, Central New York State, USA. Wetlands $26,917-927$. 
Drever, J.I., 1997. The Geochemistry of Natural Waters: Surface and Groundwater. Prentice Hall, Upper Saddle River, New Jersey 07458.

Fenner, N., Ostle, N., Freeman, C., Sleep, D., Reynolds, B., 2004. Peatland carbon efflux partitioning reveals that Sphagnum photosynthate contributes to the DOC pool. Plant and Soil 259, 345-354.

Fernández, M.A., Garcia, M., Saenz, M., 1996. Antibacterial activity of the phenolic acids fractions of Scrophularia frutescens and Scrophularia sambucifolia. Journal of Ethnopharmacology 53, 11-14.

Freeman, C., Lock, M.A., Marxsen, J., Jones, S.E., 1990. Inhibitory effects of high molecular weight dissolved organic matter upon metabolic processes in biofilms from contrasting rivers and streams. Freshwater Biology 24, 159-166.

Freeman, C., Ostle, N., Fenner, N., Kang, H., 2004. A regulatory role for phenol oxidase during decomposition in peatlands. Soil Biology and Biochemistry 36, 1663-1667.

Freeman, C., Ostle, N., Kang, H., 2001. An enzymic 'latch' on a global carbon store. Nature 409, 149-149.

Glissman, K., Chin, K.-J., Casper, P., Conrad, R., 2004. Methanogenic pathway and archaeal community structure in the sediment of eutrophic Lake Dagow: effect of temperature. Microbial Ecology 48, 389-399.

Gregorich, E., Beare, M., Stoklas, U., St-Georges, P., 2003. Biodegradability of soluble organic matter in maize-cropped soils. Geoderma 113, 237-252.

Gupta, V., Smemo, K.A., Yavitt, J.B., Fowle, D., Branfireun, B., Basiliko, N., 2013. Stable isotopes reveal widespread anaerobic methane oxidation across latitude and peatland type. Environmental Science \& Technology 47, 8273-8279. 
473 Herranz, J.M., Ferrandis, P., Copete, M.A., Duro, E.M., Zalacaín, A., 2006. Effect of allelopathic

474

475

476

477

478

479

480

481

482

483

484

485

486

487

488

489

490

491

492

493

494 compounds produced by Cistus ladanifer on germination of 20 Mediterranean taxa. Plant Ecology 184, 259-272.

Horwath, W., Paul, E., 1994. Methods of Soil Analysis: Part 2-Microbiological and Biogeochemical Properties, In: Bottomley, P., Angle, J., Weaver, R. (Eds.), Carbon, pp. 753-773.

Inglett, K., Inglett, P., Reddy, K., Osborne, T., 2012. Temperature sensitivity of greenhouse gas production in wetland soils of different vegetation. Biogeochemistry 108, 77-90.

Johnson, L.C., Damman, A.W., 1991. Species-controlled Sphagnum decay on a south Swedish raised bog. Oikos, 234-242.

Keller, J.K., Bauers, A.K., Bridgham, S.D., Kellogg, L.E., Iversen, C.M., 2006. Nutrient control of microbial carbon cycling along an ombrotrophic-minerotrophic peatland gradient. Journal of Geophysical Research: Biogeosciences 111, G03006.

Keller, J.K., Takagi, K.K., 2013. Solid-phase organic matter reduction regulates anaerobic decomposition in bog soil. Ecosphere 4, art54.

Kirschke, S., Bousquet, P., Ciais, P., Saunois, M., Canadell, J.G., Dlugokencky, E.J., Bergamaschi, P., Bergmann, D., Blake, D.R., Bruhwiler, L., 2013. Three decades of global methane sources and sinks. Nature Geoscience 6, 813-823.

Kolka, R., Sebestyen, S., Verry, E.S., Brooks, K., 2011. Peatland biogeochemistry and watershed hydrology at the Marcell experimental forest. CRC Press.

Kotsyurbenko, O., Friedrich, M., Simankova, M., Nozhevnikova, A., Golyshin, P., Timmis, K., Conrad, R., 2007. Shift from acetoclastic to $\mathrm{H}_{2}$-dependent methanogenesis in a West 
Siberian peat bog at low $\mathrm{pH}$ values and isolation of an acidophilic Methanobacterium strain. Applied and Environmental Microbiology 73, 2344-2348.

497 498

499

500 501

Medvedeff, C.A., Inglett, K.S., Inglett, P.W., 2014. Evaluation of direct and indirect phosphorus limitation of methanogenic pathways in a calcareous subtropical wetland soil. Soil Biology and Biochemistry 69, 343-345.

Mellegård, H., Stalheim, T., Hormazabal, V., Granum, P.E., Hardy, S.P., 2009. Antibacterial activity of sphagnum acid and other phenolic compounds found in Sphagnum papillosum against food-borne bacteria. Letters in Applied Microbiology 49, 85-90.

Olson, D., Griffis, T., Noormets, A., Kolka, R., Chen, J., 2013. Interannual, seasonal, and retrospective analysis of the methane and carbon dioxide budgets of a temperate peatland. Journal of Geophysical Research: Biogeosciences 118, 226-238.

Puyol, D., Sanz, J., Rodriguez, J., Mohedano, A., 2012. Inhibition of methanogenesis by chlorophenols: a kinetic approach. New Biotechnology 30, 51-61.

Rasmussen, S., Wolff, C., Rudolph, H., 1995. Compartmentalization of phenolic constituents in Sphagnum. Phytochemistry 38, 35-39.

Reddy, K.R., DeLaune, R.D., 2008. Biogeochemistry of wetlands: science and applications. CRC press.

Segers, R., 1998. Methane production and methane consumption: a review of processes underlying wetland methane fluxes. Biogeochemistry 41, 23-51.

Stalheim, T., Ballance, S., Christensen, B.E., Granum, P., 2009. Sphagnan-a pectin-like polymer isolated from Sphagnum moss can inhibit the growth of some typical food spoilage and food poisoning bacteria by lowering the $\mathrm{pH}$. Journal of Applied Microbiology 106, 967976. 
Stevens, L., 1992. Enzyme Assays: A Practical Approach, In: Eisenthal, R., Danson, M. (Eds.), The Practical Approach Series, pp. 317-335.

Swain, E.Y., Abbott, G.D., 2013. The effect of redox conditions on sphagnum acid thermochemolysis product distributions in a northern peatland. Journal of Analytical and Applied Pyrolysis 103, 2-7.

Tfaily, M.M., Cooper, W.T., Kostka, J.E., Chanton, P.R., Schadt, C.W., Hanson, P.J., Iversen, C.M., Chanton, J.P., 2014. Organic matter transformation in the peat column at Marcell Experimental Forest: Humification and vertical stratification. Journal of Geophysical Research: Biogeosciences 119, 661-675.

Turetsky, M.R., Crow, S.E., Evans, R.J., Vitt, D.H., Wieder, R.K., 2008. Trade-offs in resource allocation among moss species control decomposition in boreal peatlands. Journal of Ecology 96, 1297-1305.

Verhoeven, J., Toth, E., 1995. Decomposition of Carex and Sphagnum litter in fens: Effect of litter quality and inhibition by living tissue homogenates. Soil Biology and Biochemistry $27,271-275$.

Wang, Z., Delaune, R., Patrick, W., Masscheleyn, P., 1993. Soil redox and pH effects on methane production in a flooded rice soil. Soil Science Society of America Journal 57, 382385.

Weishaar, J.L., Aiken, G.R., Bergamaschi, B.A., Fram, M.S., Fujii, R., Mopper, K., 2003. Evaluation of specific ultraviolet absorbance as an indicator of the chemical composition and reactivity of dissolved organic carbon. Environmental Science \& Technology 37, 47024708. 
540 Whiticar, M.J., 1999. Carbon and hydrogen isotope systematics of bacterial formation and 541 oxidation of methane. Chemical Geology 161, 291-314.

542 Wickland, K.P., Neff, J.C., Aiken, G.R., 2007. Dissolved organic carbon in Alaskan boreal

543 forest: Sources, chemical characteristics, and biodegradability. Ecosystems 10, 1323-1340.

544 Ye, R., Jin, Q., Bohannan, B., Keller, J.K., McAllister, S.A., Bridgham, S.D., 2012. pH controls

545 over anaerobic carbon mineralization, the efficiency of methane production, and

546 methanogenic pathways in peatlands across an ombrotrophic-minerotrophic gradient. Soil

$547 \quad$ Biology and Biochemistry 54, 36-47.

548

549 


\section{Table Captions:}

Table 1. Characterization of soil prior to S-DOM addition. P-values are from a one-way ANOVA. Significant differences between initial and final values, within each soil, are designated by different letters $(P<0.05)$.

Table 2. Characterization of S-DOM extracts prior to incubation. P-values are from a one-way ANOVA. Significant differences between initial and final values, within each soil, are designated by different letters $(P<0.05)$. 
Table 1. Characterization of soil prior to S-DOM addition.

\begin{tabular}{|c|c|c|c|c|c|c|}
\hline & $\mathrm{pH}$ & $\mathrm{TC}$ & $\mathrm{TN}$ & $\mathrm{TC}: \mathrm{TN}$ & $\mathrm{CO}_{2}$ & $\mathrm{CH}_{4}$ \\
\hline Site & \multicolumn{4}{|c|}{-.-.-. $\mathrm{g} \mathrm{kg}^{-1}$} & \multicolumn{2}{|c|}{$\begin{array}{c}--\mu \mathrm{mol} \mathrm{g}^{-1} \text { dw soil --- } \\
\text { a } 22 \text { days }\end{array}$} \\
\hline Bog Lake Fen & $4.2 \pm 0.03^{\mathrm{C}}$ & $432.9 \pm 1.4^{\mathrm{A}}$ & $6.8 \pm 0.2^{\mathrm{B}}$ & $63.4 \pm 1.6^{\mathrm{B}}$ & $220.2 \pm 11.5^{\mathrm{C}}$ & $2.5 \pm 0.1^{\mathrm{A}}$ \\
\hline S1 Bog & $4.0 \pm 0.03^{B}$ & $446.1 \pm 0.8^{B}$ & $10.5 \pm 0.6^{\mathrm{C}}$ & $42.7 \pm 2.3^{A}$ & $109.9 \pm 10.0^{B}$ & $10.7 \pm 2.2^{\mathrm{B}}$ \\
\hline Zim Bog & $3.8 \pm 0.03^{\mathrm{A}}$ & $430.4 \pm 1.4^{\mathrm{A}}$ & $5.0 \pm 0.3^{\mathrm{A}}$ & $86.6 \pm 4.1^{\mathrm{C}}$ & $46.3 \pm 1.3^{\mathrm{A}}$ & $0^{\mathrm{NA}}$ \\
\hline
\end{tabular}


Table 2. Characterization of S-DOM extracts prior to incubation.

Phenolics DOC Protein $278 \quad$ SUVA $_{254}$

Site mg GA L $\mathrm{mg} \mathrm{CL}^{-1} \quad 278 \mathrm{~nm} \mathrm{~cm}^{-1} \mathrm{~L} \mathrm{mg}^{-1} \mathrm{C} \mathrm{m}^{-1}$ $25^{\circ} \mathrm{C} / 60^{\circ} \mathrm{C}$ extraction

\begin{tabular}{cccccc} 
& \multicolumn{5}{c}{$25^{\circ} \mathrm{C} / 60^{\circ} \mathrm{C}$ extraction } \\
\hline \multirow{2}{*}{ Bog Lake Fen } & Lawn & $6 / 30$ & $52 / 368$ & $0.65 / 2.74$ & $1.64 / 0.72$ \\
& & & & & \\
S1 Bog & Hummock & $13 / 43$ & $104 / 639$ & $2.00 / 3.91$ & $2.47 / 0.61$ \\
S1 Bog & Hollow & $9 / 29$ & $214 / 452$ & $2.61 / 2.00$ & $0.44 / 0.60$ \\
& & & & & \\
Zim Bog & Lawn & $7 / 34$ & $15 / 312$ & $0.22 / 1.94$ & $1.78 / 0.59$ \\
\hline
\end{tabular}




\section{Figure Captions:}

Figure 1. The effect of $\mathrm{S}$-DOM extracted at $60{ }^{\circ} \mathrm{C}$ amendments on anaerobic $\mathrm{CO}_{2}$ production in three soils following a 40 day anaerobic laboratory incubation (mean $\pm 1 \mathrm{SE}, \mathrm{n}=3$ ). Pvalues are from a one-way ANOVA. Significant differences between treatments, within each soil, are designated by different letters $(P<0.05)$.

Figure 2. The effect of S-DOM extracted at $60{ }^{\circ} \mathrm{C}$ amendments on $\mathrm{CH}_{4}$ production and $\delta^{13} \mathrm{C}-\mathrm{CH}_{4}$ in soils from (a) Bog Lake Fen, and (b) S1 Bog following a 40 day anaerobic laboratory incubation (mean $\pm 1 \mathrm{SE}, \mathrm{n}=3$ ). P-values are from a one-way ANOVA. Significant differences between treatments, within each soil, are designated by different letters $(P<0.05)$. Data from Zim Bog are not shown because there was no detectable $\mathrm{CH}_{4}$ production.

Figure 3. Relationship between S-DOM extracted at $60{ }^{\circ} \mathrm{C}$ derived DOC and S-DOM derived $\mathrm{CO}_{2}$ and $\mathrm{CH}_{4}$ production from Bog Lake Fen soil (a, d), S1 Bog soil (b, e), and Zim Bog soil (c) following 40 day incubation ( $\mathrm{n}=3$ per data point). S-DOM derived refers to the difference between S-DOM amended soils and unamended soils from the same site. 
Figure 1.

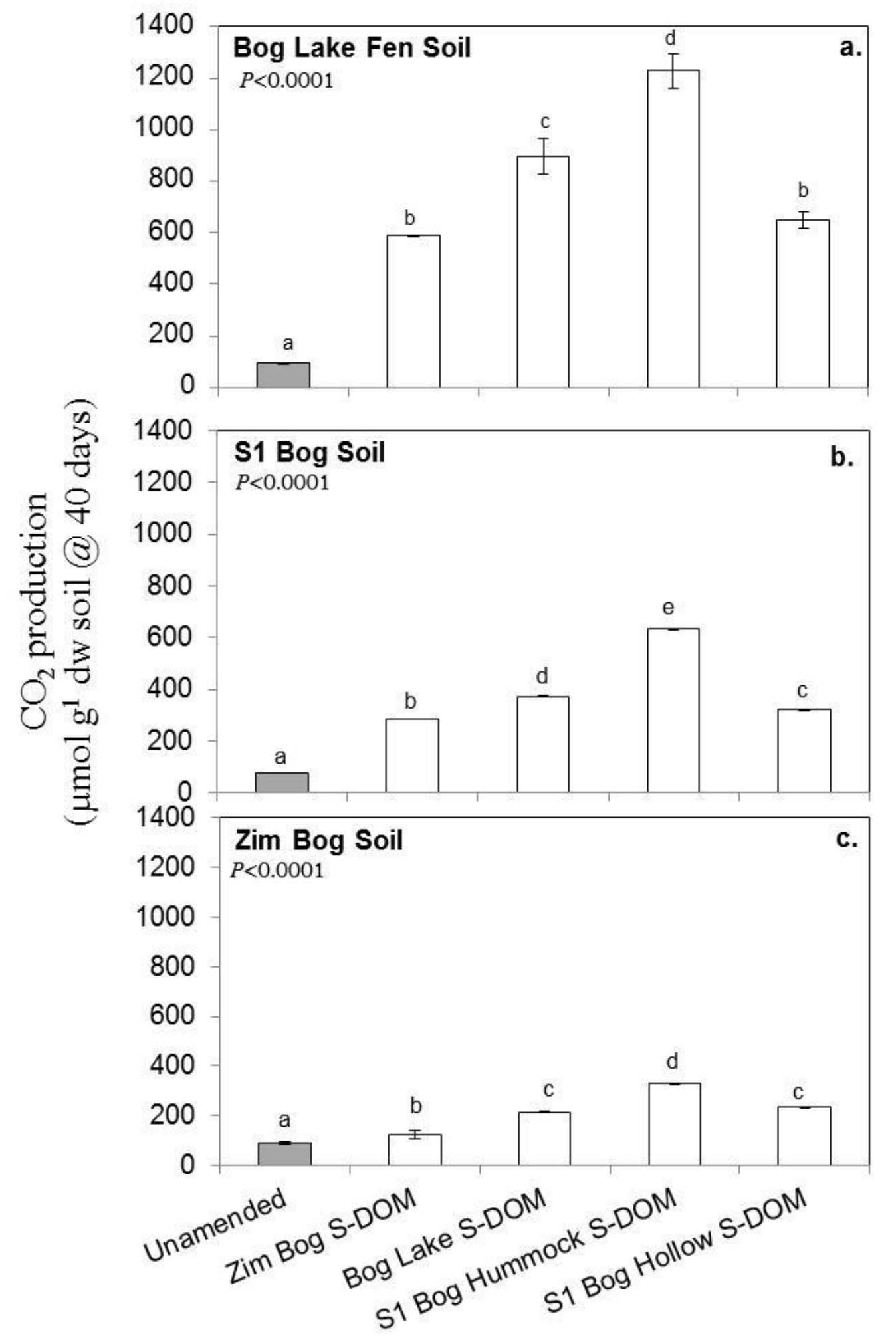


Figure 2.

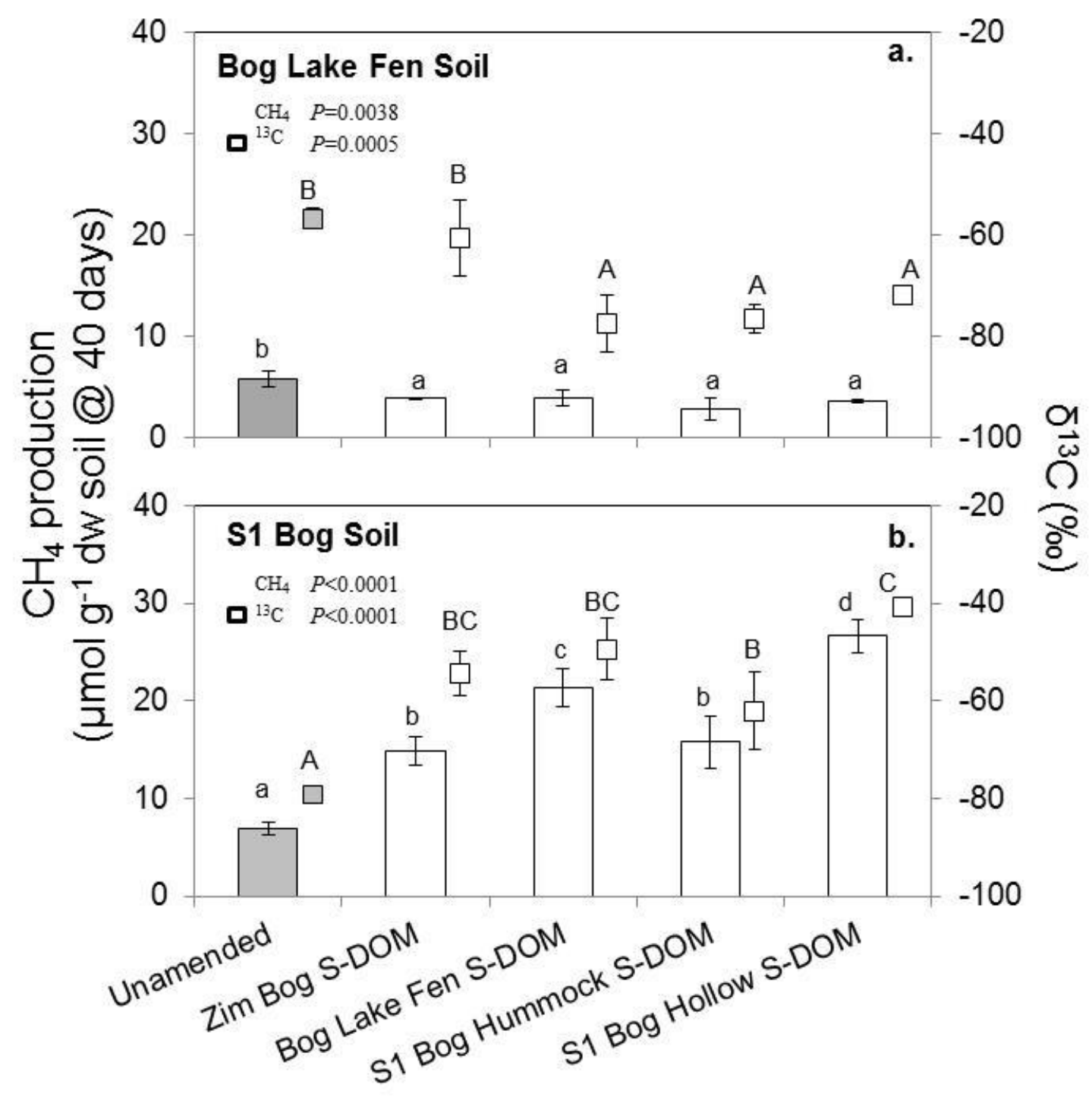


Figure 3.

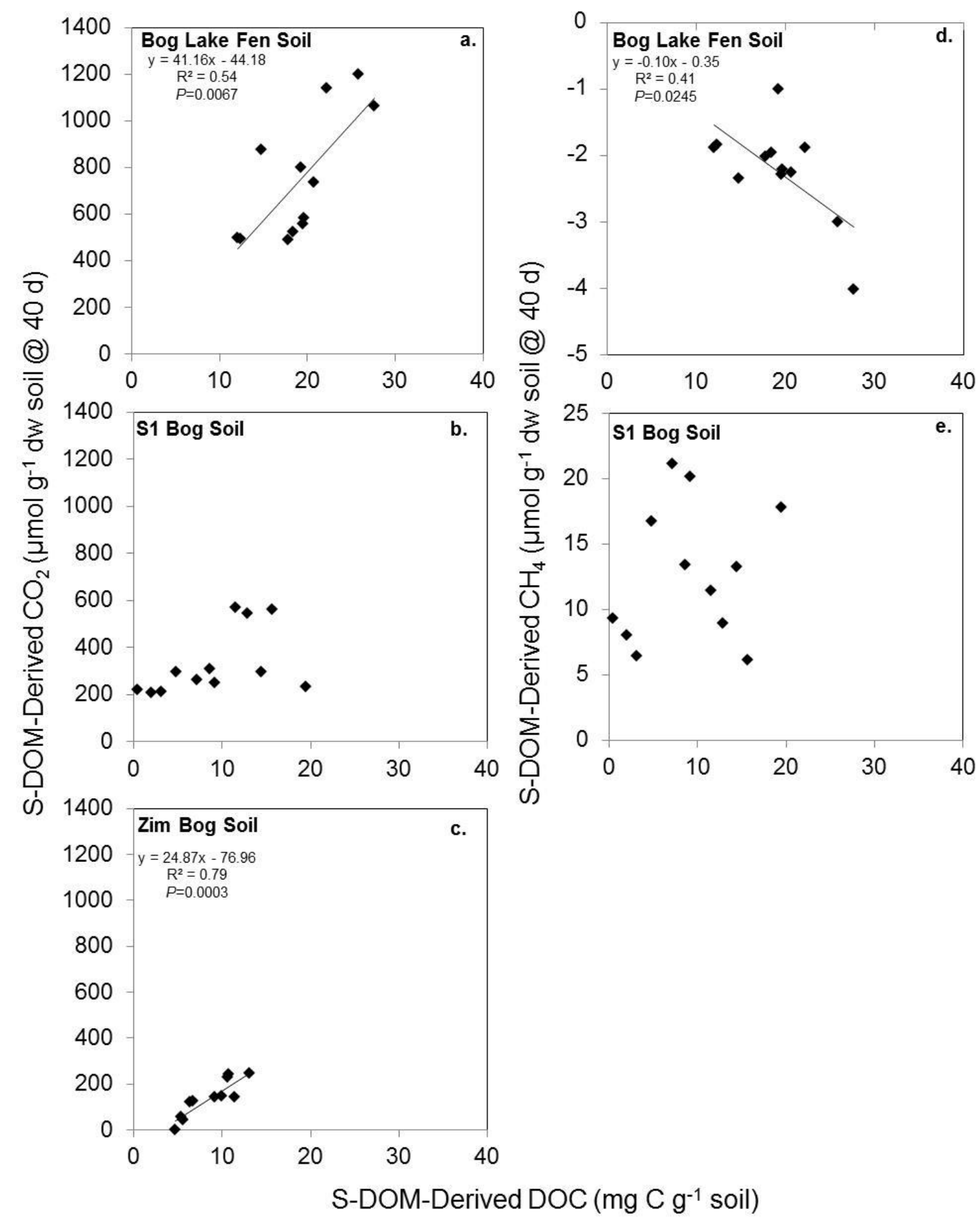

